\title{
Deformation partitioning at the rupture front in NW Himalaya: evidence from tectono-geomorphic and paleoseismic investigations
}

\author{
Anand K Pandey ${ }^{1 *}$, Prabha Pandey ${ }^{1}$, Guru Dayal Singh ${ }^{1}$, GV Ravi Prasad ${ }^{2}$, K Dutta $^{2}$ and DK Ray ${ }^{2}$ \\ 1 National Geophysical Research Institute, Uppal Road, Hyderabad - 500 007, INDIA \\ 2 AMS Radiocarbon Laboratory, Institute of Physics, Bhubaneswar - 751005, INDIA \\ *For correspondence,email: akpandey@ngri.res.in
}

The southernmost terrain defining intracrustal fault in Himalaya, Himalayan Frontal Thrust (HFT), is recognized as an abrupt topographic break separating the Sub-Himalayan Siwalik range from the Piedmont/alluvial plain. The relative relief of SubHimalaya, from Gangetic alluvium, was attained during LateQuaternary due to episodic seismic slip on HFT. Recent active tectonic studies and paleoseismic investigations have documented the surface ruptures of past earthquakes in the HFT zone, which is recognized as the locus of primary earthquake rupture front in the Himalaya. The same is responsible for the growth of various levels of starth terraces and fold growth in the mountain front.

We explored the mountain front and HFT zone to explore the deformation partitioning in the mountain front in parts of NW Himalaya. Three levels of strath terraces and shear zones in the growing Dhanaura anticline have been mapped along transverse stream sections in Himachal Sub-Himalaya. The active faults and scarp are identified and paleoseismic trench across one of the surface rupture scarp (5-7 $\mathrm{m}$ high), with considerable lateral extension in the $\mathrm{T} 1$ terrace, is carried out. The trench was excavated close to another previously explored trench (Kumar et al. 2006) on a different fault scarp. In the trench section, two imbricate splays of surface rupture fault are observed, thrusting the Middle Siwalik mudstone/sandstone over the $\mathrm{T} 1$ terrace deposits. The terrace deposits are folded by fault-propagation mechanism with thinning and truncation of the overturned limb in the footwall. The charcoal samples in the pre-earthquake surface, marked by soil development, have yielded calibrated 14C ages older than AD 1335 \pm 85 (2) suggesting that the event postdates this period. Similar timing was obtained for the adjoining trench by Kumar et al. (2006).

Analyzing the deformation characteristics of rupture in the present trench and previous trenches by Kumar et al. (2006) show distinctly contrasting structural expression. The variability in structural expressions on different fault scarps of the same age suggests that the rupture is partitioned on different splays laterally as it emerge and the front behaves more like an en echelon fault system in the Himalayan front rather than a single discreet fault. The terrace growth and fault also suggests that the strain is partitioned onto various splay faults which aid the fold growth of HFT zone.

\section{Reference}

Kumar S, S G Wesnousky, T K Rockwell, R W Briggs, V C Thakur and $R$ Jayangondaperumal. 2006. Paleoseismic evidence of great surface rupture earthquakes along the Indian Himalaya. Journal of Geophysical Research. 111: B03304, doi:10.1029/2004JB003309 